\title{
Selection of buckwheat varieties of different morphotype and their spread in Ukraine
}

Kabanets V. ${ }^{1}$, Strakholis I. ${ }^{2}$, Klitsenko A. ${ }^{3}$

Institute of agriculture of Northern East of NAAS, Zelena Str., 1, Sad, Sumy region, Sumy oblast, 42343, Ukraine; e-mail: ${ }^{1} a g r o n a u k a @ g m a i l . c o m, ~{ }^{2}$ buckwheat.isgps@gmail.com, ${ }^{3}$ amelmalarchuk@gmail.com

The purpose. To find ways of creation of the leveled variety on the complex of biological and economic attributes with the lowered factor of ratio of vegetative and generative masses of plants. Methods. Field, laboratory, mathematical-statistical. Results. It is determined that determinant attribute is monitored by several recessive genes which determine extent of reduction of units in generative zone of shoot, creating preconditions for restricted growth of plants. Features and deficiencies of modern varieties of buckwheat of determinant and inter-determinant (ordinary) morphotypes are specified. Advantages of plants of compact habit and scheme of conducting selection process are proved. Necessity of application for selection of indirect attributes which most of all correlate with productivity is specified. Selection work in both directions of creation of varieties of determinant and ordinary morphotypes is carried out. Polymorphy of populations in equal conditions is probed, and also ways of development of existing assessment of initial stock for creation adaptive on a complex of attributes varieties of buckwheat are found. Conclusions. For today selection work should be directed on the fitting buckwheat to conditions of intense production. Selection work in directions of creation of varieties of determinant and ordinary morphotypes demands revision and search of ways of development of existing assessment of initial stock that will enable to study more widely polymorphy of population.

Key words: buckwheat, variety, morphotype, determinant, inter-determinant.

https://doi.org/10.31073/agrovisnyk201811-18

Problem statement, and analysis of recent research and publications. Creating of determinant buckwheat varieties today is formed and developed area of selection of crops. The basis for the beginning of the program of creating of a number of determinant varieties was caused by biological featuries of the buckwheat culture (V.M. Klius, I.M. Strakholis, 1981).

One of the main shortcomings in the indeterminate (ordinary) varieties is the inappropriate type of plant growth and development, namely: incomplete development caused by continually non-stop unlimited growth caused by the formation of the first, second, third order branches over and over during the growing season, the large number of flowers caused by the specific complex structure of inflorescences (upper raceme/umbel), consisting of a large number of simple inflorescences. As a result, there is a redistribution of plastic substances in such a way that most are spent for increasing the vegetative mass, and not for the formation of reproductive organs. Scientists of the Institute have found a number of forms that restrain the activity of growth meristems. This is primarily a determinant type of buckwheat plants, which has a finished (terminated) stem growth, inflorescences on the main shoots end with the terminal (upper raceme), which differs from the indeterminant type of plants by the fact that the main stem ends with unlimited stem growth, inflorescence - an umbel or semi-umbel [1].

Significant advantage of determinant varieties by the yield (Sumchanka, Krupynka, Ivanna, Yuvileyna 100, Yaroslavna and Selianochka) over the indeterminant (ordinary) morphotype varieties (Slobozhanka, Simka) under equal soil and climatic conditions is reduced to the presence of properties inherent only to the determinant type. First of all, this is a high percentage of flower realization by forming of fruit, high maturation level, resistance to grains scalding and inclination. A high percentage of flower realization in fruits leads to a narrow grain to total biomass ratio, which is in the range of $1: 2.5$, whereas in the indeterminate varieties this ratio is 1:3-4.5. The stability of the anti-inclination of determinant varieties is ensured by the fact that the conductive beams in the hypocotyl have a finely porous structure and they are very closely spaced together to form a solid ring $[2,3]$. 
Great help in methodological and practical aspects of the creation of the first determinant variety of buckwheat 'Sumchanka' provided scientists-breeders from the Institute of Legumes and Cereals (Orel, Russia): Doctor of Agricultural Sciences, Professor M. Fesenko and candidate of Agricultural sciences phD G. A. Martynenko [4, 5].

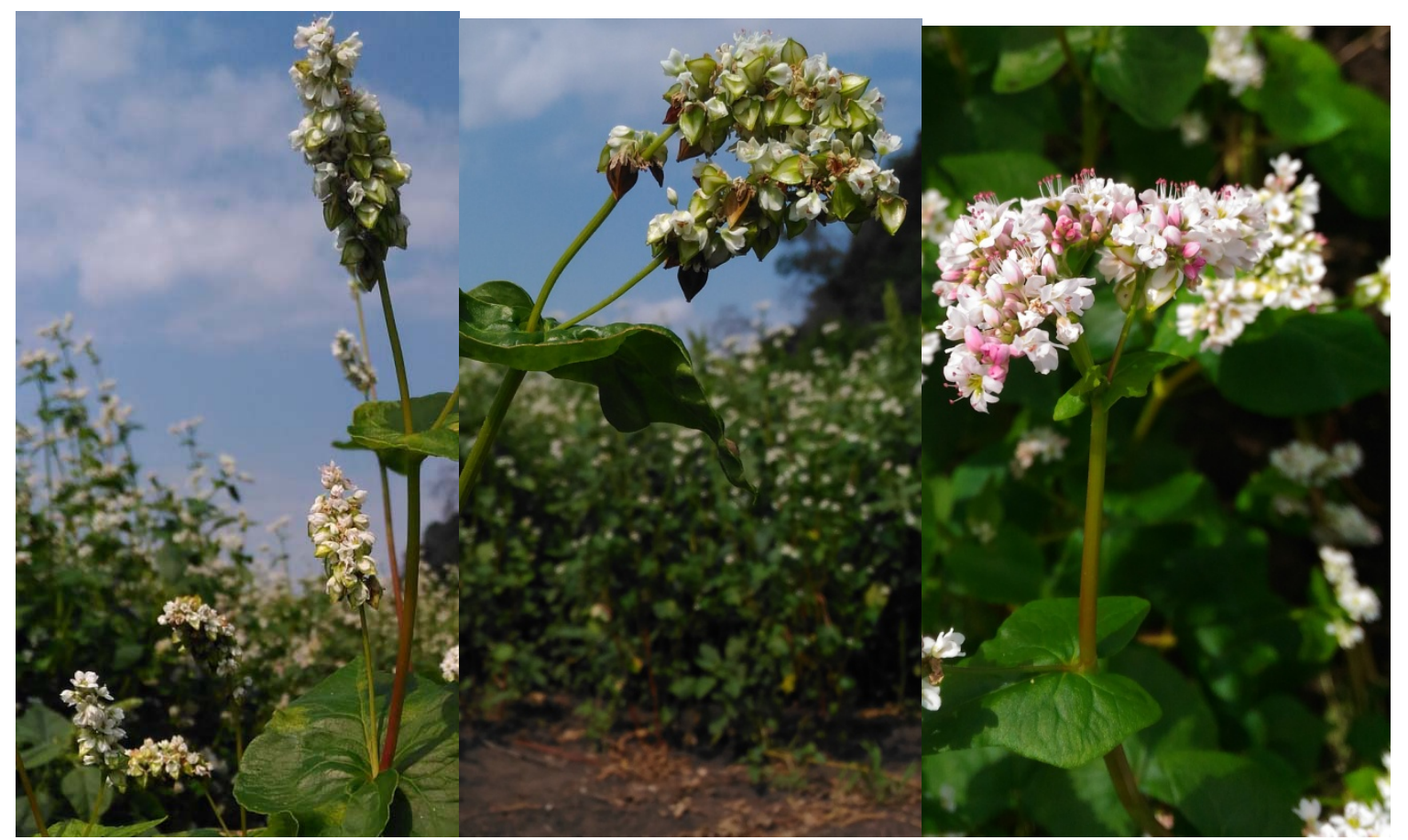

Fig.1. Forms of Inflorescence of Determinant and Ordinary (Indeterminant) morphotypes of buckwheat (1.'Sumchanka' variety - a single raceme; 2. 'Yaroslavna' variety - a double raceme; 3. Simka variety an umbel)

In the State strain testing variety showed increased competitiveness in conditions of moisture deficiencies and high temperature and was located to regions of Pavlodar, Kustanai and East Kazakhstan regions; also to Mykolayiv, Sumy and Luhansk regions of Ukraine, and in Russia - to Orenburg region and to the Republic of Kalmykia. The highest yield (4.49 t/ha) in the State varietal test was shown in 1982 at Voznesenska Research Station (Mykolaiv region) and in 1990 the world record for the yield of buckwheat at the level of 6.88 tons per hectare was achieved on the same Variety testing division (I.Katsov, V.Yegorov, 1992). The variety was accepted as valuable by the grain quality and in 1991 only in Russia it was grown on an area of 116 thousand hectares [5].

Using 'Sumchanka' variety as a basic material, several other new determinants were created at AllRussia Research Institute of Legumes and Groat Crops in cooperation with other institutions as well as in the Sumy Agricultural Research Station. One of them - 'Doschyk', created in cooperation with the Gomel Institute Resistance Center (Belarus), which in 1990 held a State strain testing in different in Ukraine. At 16 of 29 Variety testing divisions 'Sumchanka' exceeded the standard-variety by grain yield, and at 9 Variety testing divisions it was accepted as the best. 'Doschyk' ceded only in two cases of 10 Variety testing divisions where the standard variety was indeterminate 'Astra' variety. The average yield of 'Astra' in these experiments was 2.4 t/ha, 'Doschyk' - 2.7, ie 12.5\% higher. Given the genetic kinship of the varieties ('Astra' was one of the parent components in the initial population), these results indicated that determinism was used as a new life form for the buckwheat culture [5].

Today, it is known that the characteristic of determinism is controlled by several recessive genes, which determine the degree of reduction of nodes in the generative zone of shoots. From all genes the $d$ gene regulates the reduction of the number of racemes on the shoots to 3-4. Signs that were assigned to determinate are: limited type of shoots growth, as well as the end of shoots by single or double raceme [5, 6]. The limited type of growth gives the plant the benefits of forming a higher productivity. Determinant plants 
are plants of compact habitus and have the ability to grow more fruit ripening (unlike ordinary (indeterminant) morphotype varieties), which is caused by a stop in growth processes at the stage of massive fruit fastening, which is expressed in lower growth temps, unlike plants of indeterminant morphotypes. It ensures not only the equal distribution of plastic substances between the vegetative and generative masses, but also provides resistance to inclining. At the same time, the degree of grain, forming by flowers of determinant plants also have a significant advantage over indeterminant plants, which is expressed in 1.7 times more by the formed grain. Pretreatment of the leafy apparatus of such plants contributes to the faster accumulation of nutrients for the development of generative organs and the provision of fruits in the phase of their formation. Increased photosynthetic surface, which in turn is due to decreasing of number of leaves but increasing in size instead unlike indeterminant plants. This in turn provides the plants with higher endurance to the conditions of moisture lack (Lahanov, 1992).

Thus, such varieties are endowed with valuable economic features, namely, fast-growing, friendly maturation, narrow grain to straw level, resistance to grains scalding and inclination and, at the same time, high technological qualities of grain. High productivity potential and its stability in specific natural and climatic conditions are typical characteristics of such varieties. Early rates of maturation, in comparison with conventional varieties, allow the use of such varieties for the summer anfterscythered crops using, which is an actual technological trend for today [7].

Nevertheless, should be noted the important breeding and genetic role of the varieties of the ordinary (indeterminate) morphotypes, in populations which can be distinguished as forms of ordinary morphotypes, as well as determinant forms. Naturally, the genetic diversity of plants of allogame (cross-pollinated) populations is much wider than it is possible to statistically predict guided by the laws of heredity. At the same time, the primary form of the plant is the main base of breeding research, the search for new forms with this - its component. Taking this fact into account, for the first time in our institution history the indeterminant (ordinary) morphotypes varieties 'Slobozhanka' and 'Simka' were created and zoned. During the variety testing years in Variety testing divisions of Ukraine, these varieties provided an average yield of 2.3-2.5 $\mathrm{t} / \mathrm{ha}$, which is $0.02-0.03 \mathrm{t} / \mathrm{ha}$ higher than the national standard. At the same time, an important factor determining the varietal characteristic of the 'Simka' variety is its stability in terms of productivity, as well as, in contrast to its predecessor 'Slobozhanka', the level of drought-resistant, expressed by a rate 8.

Despite the fact that the main characteristic, which is the main for the variety evaluation - yield capacity/productivity, it is known that the level of inheritance of it by plants is relatively low and, therefore, the success of the selection by this characteristic is difficult to predict. Therefore, in order to develop varietal models McKay (1965) suggested that the morphological features most closely correlated with yield in different environmental conditions, that is, the model that is the most environmentally productive type of plant under certain environmental conditions, taking into account the architectonics, the corresponding soil-climatic conditions, water and nutritional regime $[8,9]$.

In the search for thebasic material for the creation of varieties of the ordinary (indeterminant morphotypes), the Institute's scientists from year to year conduct positive selections of plants, creating collections by a number of indirect characteristics, namely: the thickness of the stem, the leaf surface area, the height of the side inflorescences attachment, the attraction coefficient, the sum of negative correlations between the main parameters indexes, etc. Indirect signs in creating of a new basic material of ordinary morphotype plants have great importance, since they are the least variable and more independent from the natural climatic conditions. In breeding programs, the demand for search engines for the stability of the parental material is growing. The search for indirect characteristics and the implementation of the stages of the selection process and selection of them are now the integral part of the program for improving the methods for evaluating the buckwheat parental material by the adaptability of quantitative and qualitative characteristics and is widely used in the testing of indeterminable parental material (I.M Strakholis, A.V. Klitsenko, 2017).

As of August 2018, from 26 varieties, represented in the State Register, 10 of them are determinant morphotype, which is 39\%, 6 varieties of which were created by Institute of Agriculture of Northern East of NAAS [10]. In the world, determinant varieties are common in Russian Federation, where they occupy about 
$35 \%$ of the crops area, as well as in Japan and Slovenia. The distribution of varieties of the Institute of Agriculture in the world also carries a significant share. Such technologically valuable varieties as 'Slobozhanka', 'Sumchanka' and 'Krupynka' are common in the territory of Russian Federation, Belarus and Kazakhstan, and also are the subject of researches of scientists from China and Japan in their studies of the ecologically-geographically distant regions varieties adaptability in research countries (V.M. Kabanets, 2016). In total, the share of varieties of the Institute is $1 / 3$ of the varieties of the State Register and more than $40 \%$ of the sowing areas under buckwheat in Ukraine [11].

The aim, methods and results of research. The aim of launching breeding programs for the creation of determinant varieties and the search for adaptive indeterminate parental material, in connection with the intensification of production, was the search of ways to improve habitat of plants by selecting the appropriate forms and creating genotypes with the alleles of the rational architecture of the adaptive genome, which would provide the most rational ratio of vegetative and generative mass with the most effective redistribution of assimilants, in favor of grain production and its complete completion in stressful conditions of the environment. The most practical models for such selection can serve as a determinant form in which the development of main stem and branches more pronounced negative correlation and indeterminate forms with an attraction coefficient that does not exceed index 1 ; that also include negative correlation of medium length of internodes, the number of simply inflorescences in common inflorescence (umbel).

For these reasons, the main stages of determinant varieties creation scheme are:

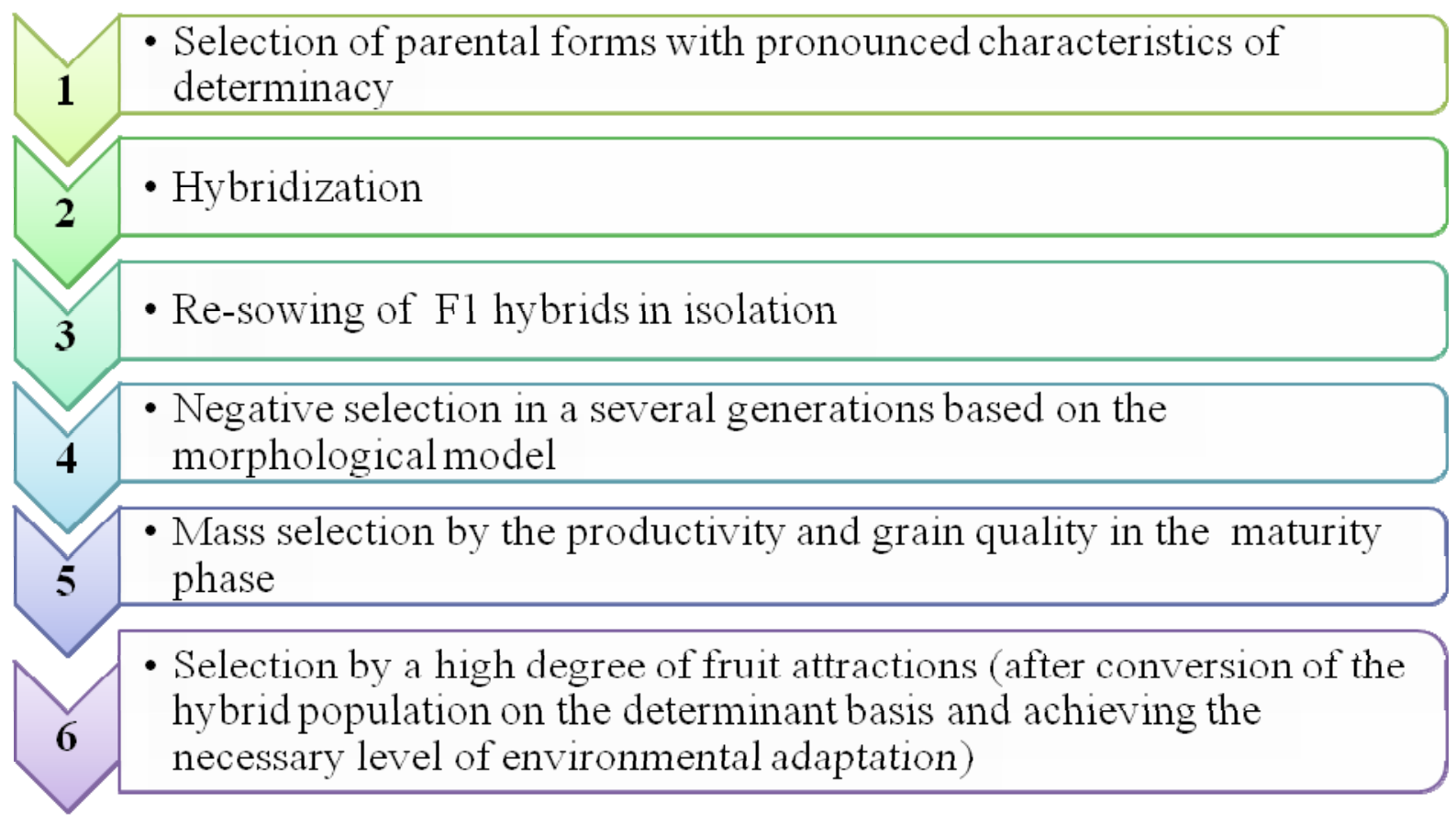

Fig.2. Stages of determinant varieties creating

Thus, the selection of parental forms is based on transgressive forms that deviate from the field of adaptive possibilities of the species. The primary source of such forms can be used polymorphism of the species, namely, samples of buckwheat of various ecological and geographical origin, local material, regional varieties, samples of the collection of VIR named after V.I. Vavilov. The model for the creation of a determinant variety should base on plants in which the development of the main stem and branches has more strongly negative correlations, and the attraction factor does not exceed 1 . It should be noted that working with determinant material, selection in the direction of increasing the length of inflorescences (racemes) leads to a decrease of realization percentage of flowers in the fruits and their mass, and selection for increasing the length of the growing season does not solve the problem of increasing productivity, leads to an increase the remontantive effect, causing asynchrony in growing on the appropriate stages of organogenesis, reduces the resistance to scalding and inclination. 
During the period from 1976 to 2018 in breeding processing were around 100 thousand of samples. Buckwheat specimens, many of which are forms and varieties breeding origin collected during research. As the result of many years of research on the stages of this scheme, based on the Institute of Agriculture of Northern East of NAAS, was the creation and introduction into production of six varieties of determinant morphotype and two of ordinary (indeterminate).

\section{Conclusions and prospects for the further research}

Today, breeding work is carried out taking into account the phenomena of climate change, as well as the difficulties in the conditions of agricultural production, namely the limited choice of factors of intensification, reduction of the culture of agriculture, as well as a number of economic factors. Production requires non-stop varieties renewing and varietal adaptation to these conditions. In such situation, new range of varieties should be geared towards adapting to intensive cultivation system.

The complexity of controlling the heredity of the determinant characteristic contributes to the simultaneous search for new ways of expanding the variety range of culture by paying attention to its primary form, which is indeterminate population of plants. Breeding work in both directions enables to investigate better the polymorphism of populations by comparing them under the same conditions, as well as to facilitate the search and improvement of the existing estimation of the basic material, based on the already studied varietal models, prospective for the creation of adaptive complexes of the characteristics of buckwheat varieties.

\section{References}

1. Fesenko N.V. (1968). Geneticheskiy faktor, obuslavlivayushchiy determinantnyy tip rasteniya u grechikhi. [Genetic factor determining determinant type of plant in buckwheat]. Moskva: Genetika. P. 163 166. [In Russian].

2. Martynenko G.A. (1982). Listoobespechennost' i ozernennost' tsvetkov u determinantnoy formy grechikhi. Selektsiya, semenovodstvo i tekhnologiya vozdelyvaniya grechikhi. [Leaf sustenance and ozernennost flowers in the determinant form of buckwheat. Selection, seed and buckwheat cultivation technology]. P. 70 - 74. [In Russian].

3. Shakhov N.F., Zelenova A.N. (1985). Anatomiya steblya grechikhi v svyazi s ustoychivost'yu k poleganiyu. Povyshenie urozhaynosti i kachestva krupyanykh kul'tur metodami selektsii i tekhnologii vozdelyvaniya (grechikha). [Anatomy of a buckwheat stalk due to lodging resistance. Increase of productivity and quality of cereal crops by methods of selection and cultivation technology (buckwheat)]. P. 63 - 71. [In Russian].

4. Fesenko N.V., Naumova G.E. (1975). Nasledovanie vetvistosti i dliny mezhdouzliy u mezhsortovykh gibridov grechikhi. [Inheritance of branching and interstitial length in intervarietal hybrids of buckwheat]. Byulleten' NTI VNIIZBK. No 11. P. 48 - 54. [In Russian].

5. Klius V.M., Strakholis I.M. (2001). Rezultaty, perspektyvy i problemy selektsii hrechky na determinantnist. [Results, perspectives and problems of selection of buckwheat on determinants]. Selektsiia $i$ nasinnytstvo: mizhvidomchyi tematychnyi naukovyi zbirnyk. No 85. P. 29 - 37. [In Ukrainian].

6. Alekseieva O.S., Taranenko L.K., Malyna M.M. (2004). Henetyka, selektsiia i nasinnytstvo hrechky. [Genetics, selection and seedling of buckwheat]. Kyiv: Vyshcha shkola. 213 p. [In Ukrainian].

7. Trotsenko V. I., Klitsenko A.V. (2017). Otsinka vykhidnoho materialu ta rozrobka modeli sortu hrechky dlia povtornykh posiviv. [Estimation of the source material and development of a buckwheat variety model for repeated crops]. Visnyk Kharkivskoho natsionalnoho ahrarnoho universytetu im. V.V. Dokuchaieva. No 2. P. 38 - 47. [In Ukrainian].

8. Yatsyshen O.L., Taranenko L.K. (2012). Fizioloho-henetychni mekhanizmy vdoskonalennia arkhitektoniky henotypiv hrechky metodamy selektsii za indeksnymy pokaznykamy. [Physiological and genetic mechanisms of improvement of architectonics of genotypes of buckwheat by selection methods by index parameters]. Zbirnyk naukovykh prats NNTs Instytut zemlerobstva. P. 134 - 144. [In Ukrainian]. 
9. Wolinska J., Wyrzykowska M., Wolinski J., Bombik A. (2010). Forecasting of seed crop of buckwheat basing on selected elements of crop structure. ADVANCES IN BUCKWHEAT RESEARCH: Proceedings of the 11th international symposium on buckwheat. P. $644-650$.

10. Derzhavnyi reiestr sortiv roslyn, prydatnykh dlia poshyrennia v Ukraini na $2018 \mathrm{r}$. [State register of plant varieties, suitable for distribution in Ukraine in 2018]. URL: http://sops.gov.ua/reestr-sortiv-roslin [In Ukrainian].

11. Stan vyrobnytstva hrechky $\vee$ Ukraini. [Condition of production of buckwheat in Ukraine]. URL: http://www.ukrstat.gov.ual [In Ukrainian]. 